\title{
Pengaruh C-Phycocyanin terhadap Kadar Soluble Glikoprotein (Sgp130) Pada Trofoblas Tikus Wistar yang Dipapar Interleukin-6 (IL-6)
}

\author{
Elizabeth Haryanti ${ }^{1 *}$, Harry K Gondo ${ }^{2}$ \\ Bagian/SMF IImu Penyakit Dalam ${ }^{1}$, \\ Bagian/SMF Obstetri dan Ginekologi² \\ Fakultas Kedokteran Universitas Wijaya Kusuma Surabaya \\ e-mail: Elizabeth@gmail.com
}

\begin{abstract}
Abstrak
Plasenta merupakan organ gabungan dari ibu dan janin. Salah satu sitokin dari plasenta adalah IL-6 yang penting bagi perkembangan plasenta normal dan kesuksesan kehamilan. Sgp130 mengikat kompleks IL6-sIL-6R, sehingga sinyal IL-6 tidak dapat di teruskan. Keduanya berperan penting dalam pre-eklampsia yang memiliki kadar IL-6 dan sgp130 tinggi yang diharapkan dapat ditekan dengan pemberian Cphycocyanin. Tujuan penelitian ini untuk membuktikan pengaruh C-phycocyanin terhadap kadar sgp130 pada trofoblas tikus wistar yang dipapar IL-6. Penelitian ini menggunakan group hewan coba dengan sampel berjumlah 25 tikus yang dibagi menjadi satu kelompok kontrol dan empat kelompok perlakuan. Dosis C-Phycocyanin (10mg, 20mg, 40mg). Hasil penelitian menunjukkan terdapat perbedaan bermakna antara kontrol dengan kelompok perlakuan IL-6, IL-6+CPC10, IL-6+CPC20. Tetapi tidak terdapat perbedaan bermakna antara kelompok kontrol dengan IL-6+CPC40, nilai sig. 0,214 (sig. <0,05). Kesimpulan. Ada pengaruh C-Phycocyanin terhadap kadar Sgp130 pada trofoblas tikus wistar yang dipapar IL-6 yaitu pada dosis C-Phycocyanin 40mg.
\end{abstract}

Kata Kunci: C-Phycocyanin, Kadar SGP130, Trofoblas, IL-6, Tikus Wistar

\section{Effect Of C-Phycocyanin on Soluble Globoprotein Content (Sgp130) on Trophoblas of Interleukin-6 (II-6) Wistar Rat}

\begin{abstract}
The placenta is a joint organ of the uterus surface mother and fetus. One of cytokines of the placenta is IL6 which is essential for normal placental development and successful pregnancy. Sgp130 binds Interleukin6-sIL-6R complex, so Interleukin-6 signal cannot be passed on. Both factors play an important role in preeclampsia which has high levels of IL-6 and sgp130. They are expected to be suppressed by administration of C-phycocyanin. The aim of this study to prove effect of C-phycocyanin on sgp130 levels among wistar rats' trophoblasts exposed to IL-6. The design of the study was Experiment, Post Test Only Control, analyse with One way Anova. The samples were 25 rats divided four treatment groups. Dose of C-Phycocyanin $(10 \mathrm{mg}, 20 \mathrm{mg}, 40 \mathrm{mg})$. The results significant difference between control and treatment group IL-6, IL-6 + CPC10, IL-6 + CPC2O. But there was no significant difference between control group and IL-6 + CPC40, sig value. 0.214 (sig. <0.05). Conclusion. There is an effect of C-Phycocyanin on Sgp130 levels in wistar rats' trophoblasts exposed to IL-6 at a dose of C-Phycocyanin $40 \mathrm{mg}$.
\end{abstract}

Keywords: C-Phycocyanin, SGP130 Level, Trophoblast, IL-6, Wistar Mouse

\section{PENDAHULUAN}

Plasenta merupakan organ gabungan dari dua bagian (ibu dan janin) dan dipertahankan oleh darah dari ibu dan janin (1). Berbagai sitokin yang berasal dari sel-sel plasenta sangat penting bagi perkembangan plasenta normal dan kesuksesan kehamilan, salah satunya adalah IL-6. Selama kehamilan, IL6 diproduksi oleh extravillous dan cytotrophoblasts untuk mengatur berbagai fungsi sel-sel tersebut, misalnya migrasi, invasi, diferensiasi trophoblast dan proliferasi (2). 
Kadar IL-6 yang tinggi seringkali terlihat dalam perubahan karakteristik profil sitokin dari penyakit seperti infertilitas yang tidak diketahui, keguguran berulang, pre-eklampsia, kelahiran prematur dan kelebihan bioavaibilitas IL-6 berpotensi menghambat perubahan transsignaling pada perempuan yang rentan keguguran melalui penghambatan pembentukan sel Treg CD4+(3), dan deregulasi dari apoptosis trofoblas berkontribusi menyebabkan kondisi yang patologis (4).

Gp130 merupakan salah satu transduser sinyal pada membran sel yang berperan meneruskan sinyal IL-6 dan sitokin-sitokin yang lain. Gp130 yang juga sebagai tranduser sitokinsitokin lain yang masih termasuk keluarga IL-6 dan berada hampir di seluruh tubuh ini, menjadikan gp130 sangat penting dalam proses regulasi seln (5). Efek IL-6 pada sel target terjadi melalui bentuk kompleks ikatan kuat dengan reseptornya IL-6R $\alpha$ dan gp130. IL-6R $\alpha$ dan gp130 juga berekspresi pada epitel dari saluran tuba falopi, dan gp130 berkontribusi pada transpor embrio ke dalam uterus (6). IL-6 dan gp130 berperan penting dalam pre-eklampsia, dimana terjadi peningkatan kadar IL-6 dan sgp130 bukan sIL-6R, penurunan ekspresi IL-6R di leukosit dan penurunan ekpresi gp130 di pembuluh endotelial dan juga leukosit, penurunan ekspresi gp130 ini menurunkan aktivitas ikatan reseptor yang menyebabkan jalur signaling JAK-STAT dan induksi SOCS-3 yang sebagai sitokin inhibitor menjadi terganggu. Hal ini menunjukkan adanya perubahan regulasi IL6 dan reseptornya selama pre-eklampsia (7).

Arthrospira merupakan alga yang dapat dimakan dan sudah diterapkan secara luas dalam farmasi sebagai tambahan suplemen untuk penambahan nilai nutrisi (8). Studi menunjukkan bahwa pemberian $A$. platensis selama 45 hari dapat menurunkan kadar sitokin pro-inflamasi: TNF- $\alpha$, IL-1 $\beta$ dan IL- 6 pada tikus dengan arthritis. Ini mengindikasikan Arthrospira memiliki efek imunomodulasi melalui berbagai jalur modulasi inflamasi (9). Penelitian sebelumnya juga telah dilaporkan bahwa C-PC secara signifikan menurunkan regulasi protein proapoptosis seperti caspase-3 dan Bax tetapi juga meningkatkan regulasi protein antiapoptosis seperti $\mathrm{Bcl}-2$ dan $\mathrm{Bcl}-\mathrm{XL}$ pada sel paru-paru tikus yang di beri perlakuan LPS (10).

\section{METODE PENELITIAN}

\section{Rancangan Penelitian}

Penelitian dengan group sampel dan dilakukan pemeriksaan satu kali pada masing masing sampel (Post Test Only Control Group Design)

\section{Lokasi Penelitian}

Tikus Wistar yang didapatkan dari UGM Jogjakarta. Persiapan, perlakuan, dan pengambilan sampel darah dilaksanakan dari bulan Agustus-Oktober 2015 di Universitas Wijaya Kusuma Surabaya.

Sampel yang diperoleh dari darah tikus dibawa ke Laboratorium Biomedik Universitas Brawijaya Malang untuk dilakukan analisa kadar sgp130. Pengiriman sampel dan analisa kadar dilakukan pada bulan Oktober 2015.

\section{Sampel Peneitian}

Sampel pada penelitian ini adalah tikus wistar betina hamil dewasa sebanyak 25 ekor dibagi dalam lima 1 kelompok kontrol dan 4 kelompok perlakuan

\section{Analisis Data}

Data terlebih dahulu diuji tingkat homogenitas dan normalitas dengan Levene's test (bermakna jika sig. > 0,05). Kemudian dilakukan uji One-Way Anova (bermakna jika sig. $<0,05)$ dengan menggunakan software SPSS 16 for windows. Jika ada perbedaan dilanjutkan Uji statistik Post Hoc-Least significant difference test (LSD) (bermakna jika sig. $<0,05$ ).

\section{HASIL PENELITIAN ANALISIS DATA}

Tabel 1. Uji Normalitas

\begin{tabular}{lclll}
\hline $\begin{array}{l}\text { Variabel } \\
\text { Penelitian }\end{array}$ & $\overline{\mathrm{X}} \pm$ SD & $p$ & Keterangan \\
\hline Kadar & $0,56 \quad \pm$ & 0,139 & $\begin{array}{l}\text { Distribusi } \\
\text { data normal }\end{array}$ \\
sgp130 & 0,27 & & data \\
\hline \multicolumn{1}{c}{ Data } & pengukuran & kadar sgp130
\end{tabular}
menunjukkan berdistribusi normal dengan nilai $p=0,139(p>0,05)$.

Tabel 2. Uji Homogenitas

\begin{tabular}{ll}
\hline \multirow{2}{*}{ Data } & Statistik Levene \\
\cline { 2 - 2 } & Sig. \\
\hline Kadar sgp130 & 0.317 \\
\hline Hasil uji Levene's test menunjukkan data kadar \\
sgo homogen dengan nilai sig. 0,317 (sig. >
\end{tabular}


$0,05)$

Tabel 3. Uji One Way Anova

\begin{tabular}{lll}
\hline \multirow{2}{*}{ Data } & \multicolumn{2}{l}{ Anova } \\
\cline { 2 - 3 } & $\mathrm{F}$ & Sig. \\
\hline Kadar sgp130 & 6.805 & 0.001 \\
\hline
\end{tabular}

Hasil uji One Way Anova data kadar sgp 130 menunjukkan perbedaan bermakna dengan sig. 0,001 ( sig. $<0,05$ ).

Tabel 4. Tabel Uji LSD Kadar Sgp130

(I) Kelompok

(J)

Kelompok

inkomplit yang menurunkan aliran darah uteroplasenta sehingga membuat plasenta iskemik dan hipoksia. Peningkatan kadar faktor antiangiogenik, debris plasenta, ROS dan sitokin pro-inflamatori mengakibatkan aktivasi sel endotelial dan kerusakan vaskular yang mengarah pada proteinuria dan hipertensi yang merupakan gejala utama dari pre-eklampsia (11).

Studi menunjukkan rilis sgp130 meningkat ketika jaringan plasenta normal dikultur dalam kondisi oksigen rendah menyerupai kadar sgp130 yang dirilis oleh

Sig.jaringan pre-eklampsia yang dikultur dalam kondisi normoksik. Ini mendukung gagasan bahwa hipoksia adalah tanda patofisiologi fungsi Kontrol IL-6 .001trofoblas dalam pre-eklampsia (12). Sgp130 dihasilkan oleh cleavage proteolitik molekul

\begin{tabular}{ccc}
\hline IL- & .00membran atau transalasi mRNA spliced \\
$6+\mathrm{CPC} 10$ & $*$ & alternatif (13).
\end{tabular}

$\frac{6+\mathrm{CPC} 10}{\mathrm{IL}-} \quad 001$ Peningkatan IL-6 pada maternal
6+CPC20 $* \quad$ memediasi aktivasi jalur JAK/STAT3 tepatnya di IL$6+\mathrm{CPC} 40$

Keterangan *: The mean difference is significant at the 0.05 level.

Uji LSD didapatkan bahwa terdapat perbedaan yang bermakan antara Kontrol dengan kelompok perlakuan IL-6, IL-6+CPC10, IL-6+CPC20 (sig. <0,05). Tetapi tidak terdapat perbedaan bermakna antara kelompok Kontrol dengan IL-6+CPC40 (sig. <0,05).

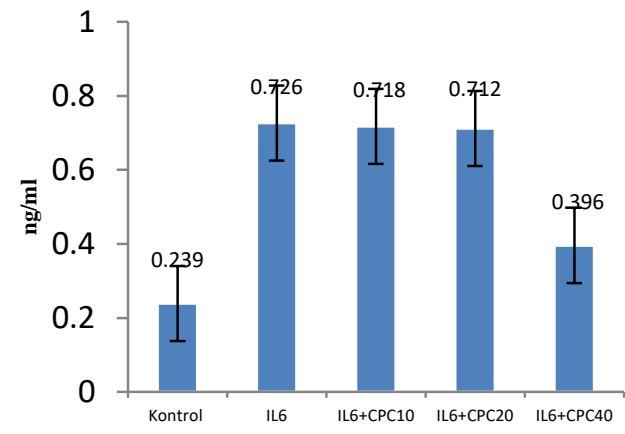

Gambar 1. Kadar IL-6

\section{PEMBAHASAN}

IL-6 merupakan sitokin pro-inflamatori yang berkaitan dengan sistem imun pada kehamilan pre-eklampsia. Pada pre-eklamsia terjadi maladaptasi pada tempat implantasi yang berkontribusi menyebabkan gangguan invasi sel trofoblas yang berikutnya pada pembentukan arteri spiral desidua menjadi lapisan spongiotrofoblas dari plasenta, yang

.214menyebabkan peningkatan ekspresi gen fase akut dan secara paralel juga mengganggu poros GH-IGF yang ditandai dengan penurunan kadar GH, IGFI dan IGFBP3 (14).

Studi Shih, 2009 telah menunjukkan CPhycocyanin (CPC) memiliki kemampuan sebagai anti pro-inflamatori namun belum diketahui jelas bagaimana pengaruhnya terhadap kadar sgp130 yang merupakan reseptor dari IL-6R yang terlarut di dalam darah dan dapat berperan sebagai pro inflamatori (15).

\section{Pengaruh induksi IL-6 terhadap Sgp130 trofoblas tikus yang diinduksi IL- 6}

Hasil penelitian pada gambar 1 menunjukkan bahwa terdapat perbedaan bermakna kadar sgp130 (nilai sig. 0,001) antara kelompok Kontrol dengan nilai rata-rata 0.239 terhadap kelompok IL-6 dengan nilai rata-rata 0.726 dimana terjadi peningkatan kadar sgp130 dibandingkan pada kontrol.

Sesuai studi yang ada bahwa kadar sgp130 signifikan lebih tinggi pada wanita dengan preeklampsia dibandingkan kelompok kontrol hamil normal dengan usia kehamilan yang sama. Peningkatan kadar Sgp130 maternal antara kelompok normal dan kelompok pre-eklampsia menjadikan ratio sgp130/sIL-6R/IL-6 lebih tinggi pada pre-eklampsia daripada kontrol hamil normal. Dalam hal ini bentuk kompleks 
Sgp130/sIL-6R/IL-6 mencegah sIL-6R/IL-6 mengikat reseptor gp130 yang menurunan ekspresi gp130 di membran sel, dan mengganggu jalur sinyal JAK/STAT dan induksi SOCS-3 secara signifikan, sehingga berkurangnya aktivitas anti-inflamasi endogen SOCS3 menjadikan kasus vaskular sel endotel pada pre-eklampsia (7).

Tidak hanya pre-eklampsia, perubahan ligan IL-6, reseptor IL-6 dan penghambatan sgp130 sangat terkait dengan berbagai komplikasi kehamilan, termasuk infertilitas, dan kelahiran prematur (16).

Peningkatan signifikan kadar sgp130 pada penderita AMI ini bisa disebabkan terlepasnya gp130 dari membran tempat melekatnya atau karena disebabkan infiltrasi netrofil dan makrofag pada infark miokardium yang bisa melepaskan sgp130 (17). Sesuai juga dengan studi pada penyakit liver kronik, tingginya sirkulasi IL-6 berlawanan dengan rendahnya respon fase akut. Terjadi peningkatan kadar IL-6 dan sgp130 plasma tetapi bukan sIL-6R pada penyakit hati kronis dan berhubungan signifikan dengan beratnya penyakit (18).

Peningkatan ekspresi sgp130 mungkin menjadi sebuah respon untuk membatasi transignaling IL-6. Peningkatan kadar sgp130 yang signifikan pada pasien dengan heart failure (HF) merefleksikan enhanced gp130/sinyal tranduser dan aktivator dari STAT3. Tingginya kadar Sgp130 telah dihubungkan dengan semua penyebab mortalitas, kematian karena cardiovascular (CV), kematian karena worsening of HF (WHF), dan hospitalisasi karena WHF. Studi menunjukkan bahwa kadar sgp130 berhubungan dengan hasil fatal di populasi usia lanjut dengan HF sistolik kronik berasal dari iskemik (19).

\section{Pengaruh pemberian dosis CPC $10 \mathrm{mg}$ dan 20mg terhadap kadar Sgp130 pada trofoblas tikus yang diinduksi IL-6}

Gambar 1 juga menunjukkan bahwa antara kelompok kontrol dengan kelompok IL$6+$ CPC10 dan kelompok IL-6+CPC20 ada perbedaan bermakna (nilai sig. 0,001) dengan nilai rata-rata kadar sgp130 masing-masing $0,239,0,718,0,712$ dimana terjadi peningkatan kadar sgp130 dibandingkan pada kontrol. Tidak adanya perbedaan bermakna antara kelompok yang diberikan CPC dengan dosis $10 \mathrm{mg}$ dan $20 \mathrm{mg}$ lebih disebabkan karena dosis CPC 10mg dan 20mg ketika diberikan secara oral mengalami degradasi dalam saluran pencernaan dan metabolit dari berat molekul rendah CPC yang sesuai dengan hasil penelitian Romay et al (20). yang membuat C-Phycocyanin tidak bisa menekan faktor pro-inflamatori pada mencit.

\section{Pengaruh pemberian CPC dosis $40 \mathrm{mg}$ terhadap kadar Sgp130 pada trofoblas tikus yang diinduksi IL-6}

Tidak ada perbedaan yang bermakna ditunjukkan Gambar 1 antara kelompok kontrol dengan kelompok IL-6+CPC40 (nilai sig. 0,214) dengan nilai rata-rata kadar sgp130 masingmasing 0,239 dan 0,396. Tidak adanya perbedaan yang bermakna bisa disebabkan oleh karena inhibisi dari infiltrasi netrofil dan makrofag yang bisa melepaskan sgp130. Sesuai dengan Ichiki T, 2007. Hal ini menunjukkan bahwa dosis CPC $40 \mathrm{mg}$ berpengaruh terhadap kelompok yang diinduksi IL6 (17).

Studi sebelumnya menunjukkan supresi kadar IL-6 pada sel astrosit yang diberi $\mathrm{H}_{2} \mathrm{O}_{2}$ yang sebelumnya diberi perlakuan CPC (21). Penurunan kadar IL-6 secara signifikan juga ditunjukkan pada pemberian diet spirulina yang mengandung CPC (22). Studi sebelumnya juga menunjukkan terjadi penurunan regulasi dari extracelluar signal-regulated kinase 1/2 (Erk $1 / 2$ ) pada sel kanker dengan pemberian PC secara in vitro. Hal ini berkaitan dengan jalur signaling dari IL-6 yang juga melalui Erk 1/2, dengan penurunan regulasi dari Erk $1 / 2$ ini kemungkinan juga merupakan efek penurunan dari kadar IL-6 sehingga hal ini juga menurunkan kadar cyclooxigenase-2 (COX-2) dan prostaglandin-2 ( $\mathrm{PGE}_{2}$ ) (23). Jadi, penurunan kadar IL-6 bisa menjadi penyebab utama dari penurunan kadar sgp130 oleh karena efek dari c-phycocyanin.

\section{KESIMPULAN DAN SARAN}

\section{Kesimpulan}

Ada pengaruh C-Phycocyanin terhadap kadar Sgp130pada trofoblas tikus wistar yang dipapar IL-6 yaitu pada kadar C-Phycocyanin $40 \mathrm{mg}$.

\section{Saran}

1. Penelitian seperti tersebut diatas dapat dilakukan dengan masa perlakuan C- 
phycocyanin yang lebih panjang dan disertai dengan observasi pada fetus.

2. Pemberian IL-6 dilakukan dengan masa yang lebih lama untuk mendapatkan keadaan patologis yang lebih baik.

3. Perlu adanya pemeriksaan lanjutan kadar STAT3, kadar Bcl-2, kadar Bax, kadar sIL-6R, Caspase-3.

\section{DAFTAR PUSTAKA}

1. Ivanov P. \& Tsvyatkovska Tsv. Placenta Changes During Pregnancy with Thrombophilia-Influences of Low Molecular Weight Heparin Therapy, Pregnancy Thrombophilia-The Unsuspected Risk, Dr Petar Ivanov (Ed.), InTech, 2013. ISBN: 978-953-51-1199-3, DOI: $10.5772 / 56912$.

2. Goyal P, Brunnert D, Ehrhardt J, Bredow M, Piccenini S, dan Zygmunt M. Cytokine IL-6 secretion by trophoblasts regulated via sphingosine1-phosphate receptor 2 involving Rho/Rho-kinase and Rac1 signaling pathways. Molecular Human Reproduction, 2013, Vol.0, No.0 pp. 1 - 11.

3. Prins J R, Gomez L N, Robertson S A. Interleukin-6 in pregnancy and gestational disorders. Journal of Reproductive Immunology, 2011. Volume 95, Issue 1, 114.

4. Hammer A. Immunological regulation of trophoblast invasion. Journal of Reproductive Immunology. 2011. Austria. 90. 21-28

5. Jones S A, Scheller J, \& John S R. Therapeutic strategies for the clinical blockade of IL-6/gp130 signaling. J Clin Invest. 2011; 121(9): 3375-3383. doi:10.1172/JCI57158.

6. Yousefian E, Novin M G, Fathabadi F F, Farahani R M, Kachouei EY. The expression of IL-6R $\alpha$ and Gp130 in fallopian tubes bearing an ectopic pregnancy. Anat Cell Biol. Sep; 46(3), 2013: 177-182. http://dx.doi.org/10.5115/ acb.2013.46.3.177

7. Wang $Y$, Lewis, D F, Gu Y, Zhao S, \& Groome, L J. Elevated Maternal Soluble Gp130 and IL-6 Levels and Reduced Gp130 and SOCS-3 Expressions in Women Complicated With Preeclampsia. Hypertension, 57(2), 2011, 336-342. doi:10.1161/

HYPERTENSIONAHA.110.163360

8. Prassad R N, Sanghamitra K, Antonia G M, Juan G V, Garay R, Luis I M J., Guillermo V V. Isolation, Identification and Germplasm Preservation of Different Native Spirulina Species from Western Mexico. American Journal of Plant Sciences, 2013, 4, 65-71. http://dx.doi.org/10.4236/ajps.2013.412A 2009

9. Kumar $\mathrm{N}$, Kumar $\mathrm{P}$, Singh $\mathrm{S}$. Immunomodulatory effect of dietary Spirulina platensis in type II collagen induced arthritis in rats. Research Journal of Pharmaceutical, Biological and Chemical Science. 2010, pp 877-885. ISSN: 09758585.

10. Leung $P$, Lee $H \mathrm{H}$, Kung $Y C$, Tsai $M F$, \& Chou T C. "Therapeutic Effect of CPhycocyanin Extracted from Blue Green Algae in a Rat Model of Acute Lung Injury Induced by Lipopolysaccharide," EvidenceBased Complementary and Alternative Medicine, vol. 2013, Article ID 916590, 11 pages, doi:10.1155/2013/916590

11. Lockwood Charles J, Yen Chih-Feng, Basar Murat, Kayisli Umit A, Martel Maritza, Buhimschi Irina, et al. PreeclampsiaRelated Inflammatory Cytokines Regulate Interleukin-6 Expression in Human Decidual Cells. The American Journal of Pathology, 2008, vol. 172, No. 6, DOI: 10.2353/ajpath.2008.070629

12. Zhao $S, G u Y$, Dong $Q$, Fan $R$, Wang $Y$. Altered Interleukin-6 Receptor, IL-6R and gp130, Production and Expression and Decreased SOCS-3 Expression in Placentas from Women with Pre-eclampsia. Placenta 29. Elsevier Ltd. 2008. 1024-1028.

13. Dovio A, Perazzolo L, Saba L, Termine A, Capobianco $M$, Bertolotto A. High-dose glucocorticoids increase serum levels of soluble IL-6receptor $a$ and its ratio to soluble gp130: an additional mechanism for early increased bone resorption. European Journal of Endocrinology; 2006. 154 745-751; ISSN 0804-4643

14. Hsiao E Y., Patterson P H. Activation of the maternal immune system induces endocrine changes in the placenta via IL-6. Brain, Behavior, and Immunity, 2011. Vol. 25, Issue 4, Pages 604-615, ISSN 08891591, http://dx.doi.org/10.1016/j.bbi.2010.12.0 17. 
ISSN 1978-2071 (Print); ISSN 2580-5967 (Online) Jurnal IImiah Kedokteran Wijaya Kusuma 6 (1) : 23-28

15. Shih $C M$, Cheng $S$ N. Wong $C S$, Kuo $Y L$, Chou $T$ C. Antiinflammatory and Antihyperalgesic Activity of C-Phycocyanin. International Anesthesia Research Society. 2009: Vol. 108, No. 4. DOI: 10.1213/ane.0b013e318193e919

16. Wicherek $M$ D, Kaźmierczak $W$, Gręźlikowska U. The Complex Role Of II-6 In Physiology And Pathology, Archives Of Perinatal Medicine. 2013. 19(3), 145-149.

17. Ichiki $T$, Jougasaki $M$, Setoguchi $M$, Shimokawahara $H$, Nakashima $H$, Matsuoka T, et al. Plasma Levels of Soluble Glycoprotein 130 in Acute Myocardial Infarction. J Cardiol, 2007; 502 : $101-109$

18. Lemmers A, Gustot T, Durnez A, Evrard S, Moreno C, Quertinmont E, et al. An inhibitor of interleukin- 6 trans-signalling, sgp130, contributes to impaired acute phase response in human chronic liver disease. British Society for Immunology, Clinical and Experimental Immunology, 2009, 156: 518-527. doi:10.1111/j.13652249.2009.03916.x

19. Askevold E T, Nymo S, Ueland T, Gravning $\mathrm{J}$, Wergeland R, Kjekshus J, et al. Soluble Glycoprotein 130 Predicts Fatal Outcomes in Chronic Heart Failure. American Heart Association. 2013; 92-98 DOI:10.1161/ CIRCHEARTFAILURE.112.972653

20. Romay Ch, González R, Ledón N, Remirez D, \& Rimbau V. C-Phycocyanin: A Biliprotein with Antioxidant, AntiInflammatory and Neuroprotective Effects. Current Protein and Peptide Science, 2003, 4, 207-216.

21. Min S K. Park J S, Luo L, Kwon Y S, Hoo Lee $\mathrm{C}$, Jung $\mathrm{H}$, et al. Assessment of Cphycocyanin effect on astrocytesmediated neuroprotection against oxidative brain injury using $2 \mathrm{D}$ and $3 \mathrm{D}$ astrocyte tissue model. Scientific Reports, 2015. 5:14418. DOI: 10.1038/srep14418

22. Davis S G, Bickford P C. Short Communication: Neuroprotective Effect of Spirulina in a Mouse Model of ALS. The Open Tissue Engineering and Regenerative Medicine Journal, 2010; Vol. 3. 36-41.

23. Ravi M, Tentu S, Baskar G, Prasad S R, Raghavan S, Jayaprakash P, et al. Molecular mechanism of anti-cancer activity of phycocyanin in triple-negative breast cancer cells. BMC Cancer, 2015; 15:768 DOI 10.1186/s12885-015-1784-x 